\title{
Participatory Management of Muscles Strengthening of Core Stability and Lower Extremity to Reduce of Premenstrual Syndrome
}

\author{
Hartono Diono \\ Akademi Kebidanan Graha-Mandiri Cilacap, Indonesia \\ hartonoygmc@yahoo.com
}

\begin{abstract}
Competence to reduce of premenstrual syndrome must be have each student, so physically and psychologically able to do activities Tridharma Colleges well. One of the efforts that can reduce of premenstrual syndrome is doing muscles strengthening of core stability and lower extremity. The purpose of the research to prove that participatory management model of muscles strengthening of core stability and lower extremity can reduce of premenstrual syndrome for students of Cilacap Graha-Mandiri Midwifery Academy, in Central Java. The research used was pre-experimental quantitative research design with form of One-Group Pretest-Postest Design. The results of t-test of significance of the score obtained related $0.000<0.05$, or $t_{\text {count }}=16.741>t_{\text {table }} \alpha 0.05$, df $34=2.031$; therefore $\mathrm{H}_{0}$ is rejected and $\mathrm{H}_{\mathrm{a}}$ is accepted. It's meaning Participatory management model of muscles strengthening of core stability and lower extremity can reduce of premenstrual syndrome for students of Cilacap Graha-Mandiri Midwifery Academy, in Central Java. Conclusion, participatory management model of muscles strengthening of core stability and lower extremity can reduce of premenstrual syndrome for students of Cilacap Graha-Mandiri Midwifery Academy, in Central Java.
\end{abstract}

Keywords: Core Stability; Lower Extremity; Muscles Strengthening; Participatory Management Model; Premenstrual Syndrome.

\section{Introduction}

Premenstrual syndrome are symptomes felt by a women on one or two weeks ahead of a major impact on menstrual function of physical and social functions like breast discomfort, abdominal pain, bloating, headache, fatique, depression, anger, and anxiety [1]. Menstruation is an indicator of sexual maturity in young women, therefore required an effort reduce the accompanying syndrome. Mentruation is a natural process associated with cycle reproductive in women and young women. This is not a desease, but if management is not done appropriately will produce health problems relating to the social, cultural and religious practices. Pain during menstrual periods (dysmenorrhea) often accompanies medically in explanation. Study in New Zealand that at the time of the menstrual pain reported $53 \%$ occur in women aged 16-54 with $12 \%$ reported pain which requires absence from school or work[2].

Formulation of the problem in this research is: What is the participatory management model of muscle strengthening of core stability and lower extremity can reduce of premenstrual syndrome for students of Cilacap Graha Mandiri Midwifery Academy, in Central Java? Meaning of muscles 
strengthening to produce a high muscle endurance in performing the activity and is resistant to fatique. This can be achieved with the use oxygen. Slow-twitch muscle fibers assotiated with aerobic work, small power and survive in the long term, resistance to fatique. Aerobic exercise is conducted in the presence of oxygen at the intensity of the submaximal during a specific time period.

Research with the title The relationship between excercise and premenstrual syndrome, obtained results that regular physical exercise and sustainability can be made effective in preventing premenstrual syndrome [3]. Research with the title Effect of home based stretching exercise and menstrual care on primary dysmenorrhea and premenstruai symptome among adolescent girls, it was concluded that the use of stretching exercises combined with reguler menstrual treatment will be effective to reduce the intensity of the pain and dysmenorrhea on premenstrual symptome [4]. Research with title Effect of yoga exercise on premenstrual symptome among female in Taiwan, it was concluded the participation of women employees in the form of yoga exercise intervention reported that yoga exercise can reduce premenstrual syndrome and can improve the health of women employees [5]. Research in a summary of his research explains that stregthening the core has a strong theory base to prevention of low back pain, as shown by the clinic users widely. Studies have shown that this program can help decrease pain and improve function in patients with disorders of the low back pain [6]. That core stability providing some advantage against the musculoskeletal system, so the finesse and the maintenance of core stability became a major concern for physical therapist, athletic trainers, and musculoskeletal reseachers. Core stability is the ability of the lumbo-pelvic hip complex to prevent buckling and refund the balance after disturbance. The existence of a clear relationship between the activity of the muscles of the trunk and the lower extremity movement [7].

A good core stability is the use of the right muscles at the right time at the right intensity to control trunk appropriately for movement of the body, the upper extremity and the lower extremity. The muscles of the body consist of stabiliser (local muscles) and movement (global muscles). The deep stabilising muscles form as muscular cylinder to support of the spine and the pelvis. The main deep stabilising muscles are the transversus abdominis, pelvic floor, multifidus and diaphragm. The deep stabiliser muscles work together as a unit to hold of the trunk stable. While global muscles for move of the body, the upper extremity and the lower extremity.

Every student in the process of participatory management model for muscles strengthening of the core stability and lower extremity must be active involvement since the planning, organizing and coordinating, and evaluating. Participatory management is the process of subordinate partisipation (as members) in taking decisions together wit the superiors in an organization. The decisions taken in the participatory management better than the decisions taken individually, because in the participatory management can make decisions that can be widely accepted [8]. Research results the importance of understanding the participatory management in creating job satisfaction for employees of the public administration. In summary of this research, that prticipatory management can increse job satisfaction for the employees of the public administration [9]. Human resources development is framework to develop skills, knowledge, learning new theory, and concept of the new behavior [10]. To achieve the goal that has been set in the participatory management, then needed a proper management through planning, organizing, coordinating, and controlling. The principle of participatory management are: (1) based on trained, used to find the way out this needs; (2) used to impart new knowledge, new skills and also to build their awarness; (3) responsible for their learning, because participation in the entire process of training appreciated. 


\section{Research Methods}

The research method used was pre-experimental quantitative research design with a form of OneGroup Pretest-Postest Design. It is sait pre-experimental design, because there is still external variables that effect on the formation of the dependent variable. So the results of experiments in the form of the dependent variable is not solely affected by the independent variable, due to the absence of control variables and samples were not selected at random [11]. The population of this research is the whole of students (35 student) on 2017 at Cilacap Graha-Mandiri Midwifery Academy, in Central Java. So this reseach is not taking samples but use the whole population.

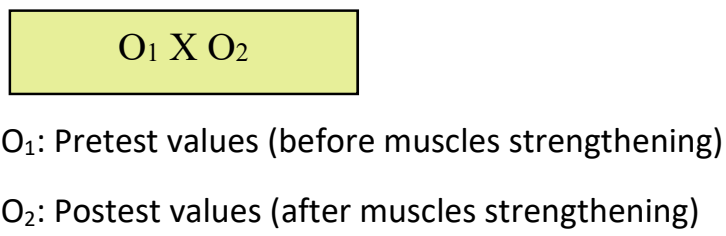

The instruments used to data collection is an instrument of assesment of physical and psychologocal state of the premenstrual syndrome before and after muscle trengthening of core stability and lower exttremity. Instrument in the form of Likertz scale, by score 5 when the answer is very fit, by score 4 if the answer is match, by score 3 if the answer is less appropriate, by score 2 when the answer is not appropriate, and by score 1 when answer is not very appropriate. The instrument has been validity and reliability test. The validity test using internal validity by use the analysis of grain, that correlate to the score of each grain with a total score. The grain has positive correlation with total score as well as a high correlation, suggesting that these grains have a high validity. The requirement set a valid value when the correlation score grains with a total score $r=0.3$; grain which have $r$ less than 0.3 is declared invalid, so it can't be used to data collection [12]. Test the reliability of the instrumen is carried out by internal consistency, Cronbach's Alpha. The instrument has reliable when score Cronbach's Alpha greater than 0.60 [12].

The data collection is the primary data collection techniques, with using questionaries. A questionaire given to the respondents to conducts an assesment of physical and psychological changes leading up to menstruation. The questionaire is given twice, i.e prior to the strengthening of the muscle of the core stability and lower extremity. After doing muscle strengthening for five weeks conducted an assesment against for premenstrual syndrome.

Two different test sample data interval, needed normality data with the Chi Squared, with SPSS computing. The value of the Chi Square count compared to the Chi Squared table. When the price of the Chi Squared count less than or equel to $(\leq)$ Chi Squared table, this data is normal distrution, and when the Chi Squared count larger $(>)$ Chi Squared table, this data is not normal distrution. Comparisons of two samples related data assesment of premenstrual syndrome before and after muscles strengthening of core stability and lower extremity, was done with technique Paired Sample t-test.

\section{Results and Discussion}

Validity and reliability test of data collection instruments of premenstrual syndrome is as follows. Instrument for respondent in 31 young women who are not included in this research respondent. The entire item instruments meets the requirements of test validity with this score (Pearson Correlation) $\geq 0.3$. Reliability test obtained score Cronbach's Alpha of 0.726 . This means that the whole matter of 
items declared valid and reliable to be used for data collection of premenstrual syndrome for stuudent of Cilacap Graha-Mandiri Midwifery Academy, in Central Java.

Results of the data assesment of premenstrual syndrome before and after muscles strengthening of core stability and lower exteremity by participatory management model for 35 student at Cilacap Graha-Mandiri Midwifery Academy, in Central Java as follow. Test normality data of premenstrual syndrome before muscles strengthening obtained a score of Chi-square count $=7.686<$ Chi-square table with $\alpha 0.05 \mathrm{df} 5=11.070$; this means that the data is normal distribution. Test normality data of premenstrual syndrome after muscles strengthening obtained a score of Chi-square count $=9.114$ $<$ Chi-square table with $\alpha 0.05 \mathrm{df} 7=14.067$; this means that the data is normal distribution.

The results of t-test of related, that participatory management model of muscles strengthening of core stability and lower extremity obtained score significance $0.000<0.05$, or $t_{\text {count }}(=16.714)>t_{\text {table }} \alpha 0.05$ with df $34(=2.031)$; therefore $H_{0}$ is rejected and $H_{a}$ is accepted. That meaning participatory management model of muscles strengthening of core stability and lower extremity can reduce of premenstrual syndrome for students at Cilacap Graha-Mandiri Midwifery Academy, in Central Java.

Table: Paired Samples Test

\begin{tabular}{|c|c|c|c|c|c|}
\hline \multirow{2}{*}{} & \multicolumn{2}{|c|}{ Paired Differences } & \multicolumn{2}{|c|}{} \\
\cline { 2 - 6 } & \multicolumn{2}{|c|}{$\begin{array}{c}\text { 95\% Confidence Interval of } \\
\text { the Difference }\end{array}$} & \multicolumn{2}{|c|}{ df } & Sig. (2-tailed) \\
\cline { 2 - 6 } & Lower & Upper & t & & \\
\hline $\begin{array}{c}\text { Pair 1 } \\
\text { Before-After Strengthening } \\
\text { Exercises } \\
\text { (Participatory } \\
\text { Management Model) }\end{array}$ & 3.71441 & 4.74273 & 16.714 & 34 & .000 \\
\hline
\end{tabular}

Competence to reduce of premenstrual syndrome should be owned each student at Cilacap GrahaMandiri Midwifery Academy, in Central Java. So, students have high productivity and high quality in implementation of college tridharma. Participatory management model of muscles strengthening is the process of muscles reinforcement with the active participation of students since in the planning, organizing, actuating, and controlling by self-evaluation. Participatory management model of muscles strengthening is the process of reinforcement the muscle with participants participation actively, since planning, organizing, actuating, and controlling through self-evaluation. The principles of participatory training is centered on the participants, used to impart new knowledge and skills, and is responsible for the results of their studies [10]. Each participant be active, have a high motivation and commitment to drive itself into the leaners who are responsible for the results of their studies, so as to achive the prescribed competence. This in in line with the results of reseach conducted $[8,9]$, participatory management that can make decisions and that can be widely accepted and can be increase job satisfaction.

"Pain is an unpleasant sensory and emotional experience. State is frequently associated with tissue damage or potential tissue damage, although pain can be experienced independently of tissue damage [13]". Muscles strengthening of core stability will have impact on high durabilty in maintaining postural control, so that it is able to control the gestures and motion control of upper and lower extremity well. Postural muscle contraction (core stability) that are synergically with contraction of lower muscle extremity will help the circulatory system of blood veins of the lower extremity, abdominal and pelvic cavum into the heart circulation. The circulation of blood (venous) means transportation of the remains of the metabolism and the rest of inflamation such as menstruation that 
Hartono Diono; Participatory Management of Muscles Strengthening of Core Stability and Lower Extremity to Reduce of Premenstrual Syndrome. Advances in Image and Video Processing, Volume 6 No 1, February (2018); pp: 18-24

occurs at the endometrium (uterus) to be transported went into circulation the veins leading to the heart of the well. Instead, the organ of the abdominal cavum and pelvic cavum (including uterus) will gain arterial blood circulation to get the needed metabolic materials needs. The state thus means the pain that accompanies menstruation will be reduced.

The results of such as reseach are in line and strengthen the results of reseach that has been done by the following reseachers. (1) the relationship between exercise and premensrual syndrome, obtained results tha regular physicsl exercise and sustainability can be made effective in preventing premenstrual syndrome [3]. (2) research with titleEffect of home based stretyching exercise and menstrual care on primary dysmenorrhea and premenstrual synptomes among adolescent gilrs, in their conclusion that the use of stretching exercises that combined with regular menstrual treatment will be effective to reduce the intensity of the pain and dysmenorrhea on premenstrual symptoms [4]. (3) reseach with title Effect of yoga exercise on premenstrual symptoms among female employees in Taiwan. In conclusion, the participation of women employees in the form of yoga exercise intervention reported that yoga exercise can reduce premenstrual syndrome and an improve the health of women employees [5]. (4) In summary of their research explain that strengthening the core has a strong base of theory in reinforcement and prevention of low back pain, as well as on suffering musculoskeletal as shown by the clinic users of widely. Stidies have shown that this program can help decrease pain an improve function in patients with disorders of the low back pain [6]. (5) explain that core stability providing some advantage against the musculoskeletal system, so the finess and the maintenance of core stability became a major concern for physical therapist, athletic trainers, and musculoskeletal researchers. Core stability is the ability of the lumbo-pelvic hip complex to the prevent buckling and refund the balance after disturbance. The existence of the trunk and the lower extremity movement. The drop in the core stability can be as predisposing the onset of trauma on the lower extremity [7].

\section{Conclusion}

Based on the results and analysis of the data, it can be concluded that participatory management model of muscles strengthening of core stability and lower extremity can reduce of premenstrual syndrome for students on 2017 at Cilacap Graha-Mandiri Midwifery Academy, in Cntral Java.

The implication, the student has competence reduce to premenstrual syndrome will use the physical capacity and capability in carrying out its current status tridharma colleges so that it will have superior quality productivity.

Recomendation, for Cilacap Graha-Mandiri Midwifery Academy, Central Java, through the study program to implementation of the participatory management model of muscles strengthening of core stability and lower exttremity for all of the students, so each of student have high quality in implementation of tridharma colleges. 


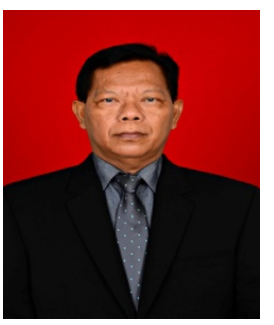

Hartono was born in Yogyakarta, May 12, 1953. He joined the Bachelor Study Program Guidance and Counseling in Semarang State University, Indonesia in 2000. Then he continued Graduate Study Program Guidance and Counseling in Semarang State University, Indonesia in 2002. He subsequently majored bachelor of applied science on a course of physiotherapy at Surakarta Muhammadiyah University, Indonesia in 2009. The last is Philosophy Doctor in Educational Management at Semarang State University, Indonesia in 2016. He worked as a school teacher teaching health nurses from 1994 to 2001. And then as a lecturer at Cilacap GrahaMandiri Midwifery Academy, in Central Java, Indonesia since 2001.

\section{REFERENCES}

[1] Ramadani, M. 2012. Premenstrual Syndrome (PMS). Jurnal Kesehatan Masyarakat, September 2012Maret 2013, Vol. 7, No.1. [On-line]

Diunduh jurnal.fkm.unand.ac.id/index.php/jkma/article/view/103/109

[2] House, S., Thérèse M., \& Sue C. 2012. Menstrual Hygiene Matters: a resource for improving menstrual hygiene around the world. First Edition. Water Aid. [On-line] Diunduh: www.wateraid.org/ /media/Files/Global/MHM\%20files/Compiled LR.pdf

[3] Safarzadeh, A. Sadegh, Z., Saeedeh R. Y. 206. The relationship between Exercise and premenstrual syndrome. [On-line] Diunduh www.ijmrhs.com/.../the-relationship-between-exercise-andpremenstrual-syndrome.pd

[4] Aboushady, R.M-N., Tawheda M. K. El-s. 2016. Effect of Home based Stretching Exercises and Menstrual Care on Primary Dysmenorrhea and Premenstrual Symptoms among Adolescent Girls. IOSR Journal of Nursing and Health Science (IOSR-JNHS) e-ISSN: 2320-1959.p- ISSN: 2320-1940 Volume 5, Issue 2 Ver. IV (Mar. - Apr. 2016), PP 10-17 [On-line] Diunduh: www.iosriournals.org/iosrinhs/papers/vol5-issue2/Version-4/B0502041017.pdf

[5] Tsai, S-T. 2016. Effect of Yoga Exercise on Premenstrual Symptoms among Female Employees in Taiwan. Int. J. Environ. Res. Public Health. 13, 721; doi:10.3390/ijerph13070721 [On-line] Diunduh www.mdpi.com/journal/ijerph

[6] Akuthota, V., , Andrea, F., Tamara, M., Michael, F. 2008. Core stability exercise principles. Curr. Sports Med. Rep., Vol. 7, No. 1, pp. 39Y44. [On-line] Diunduh: V Akuthota, A Ferreiro, T Moore... - Current sports medicine ..., 2008 - journals. Iww.com

[7] Willson, J.D., Christopher, P. D., Mary, L. I., and Irene, McC. D. 2014. Core Stability and Its Relationship to Lower Extremity Function and Injury. The Journal of the American Academy of Orthopaedic Surgeons. DOI: 10.5435/00124635-200509000-00005

[8] Shagholi, R., Reza A., Ali A. M. 2011. New Approach in Participatory Management, Concepts and Applications. [On-line] Diunduh: www.sciencedirect.com/science/article/pii/S1877042811002618 Procedia Social and Behavioral Sciences 15 (2011) 251-255

[9] Stefanovska-Petkovska, M., Marjan B., Vesna V. S. 2014. The role of participatory management in fostering job satisfaction among public administration employees. [On-line] Diunduh https://www.msm.nl/resources/uploads/2014/09/MSM-WP2014-27.pdf Tanggal 23 September 2017 
Hartono Diono; Participatory Management of Muscles Strengthening of Core Stability and Lower Extremity to

Reduce of Premenstrual Syndrome. Advances in Image and Video Processing, Volume 6 No 1, February (2018); pp: 18-24

[10] Hartono, 2016. Pengembangan Model Pelatihan Partisipatif Penulisan Artikel Ilmiah Hasil Penelitian bagi Para Dosen pada Program diploma Kebidanan pada Perguruan Tinggi Swasta di Jawa Tengah. Disertasi. Semarang: Program Pascasarjana Universitas Negeri Semarang.

[11] Sugiyono. 2010. Metode Penelitian Pendidikan Pendekatan Kuantitatif, Kualitatif, dan R\&D. Bandung: CV Alfabeta

[12] Sugiyono. 2013. Metode Penelitian Manajemen. Bandung: CV Alfabeta

[13] Lundy-Ekman, Laurie. 2013. Neuroscience: Fundamental for Rehabilitations, Fourth Edition ISBN: 978-1-4557-0643-3 United States of America: Saunders, an imprint of Elsevier Inc. 